Фащевська О. М., к.е.н., с.н.с. ДУ «Інститут економіки та прогнозування Національної академії наук України» м. Київ, Україна

DOI: https://doi.org/10.30525/978-9934-26-145-9-10

\title{
МЕТОДИ ОЦІНКИ ІНКЛЮЗИВНОСТІ РОБОЧОГО МІСЦЯ У РОЗВИТКУ ЛЮДСЬКОГО КАПІТАЛУ ПРАЦІВНИКІВ
}

Стимулювання розвитку людського капіталу працівників $\epsilon$ актуальним завданням керівних органів, кадрових підрозділів та власників підприємств усіх розмірів та форм власності. Враховуючи актуальний економічний тренд до впровадження інклюзивності в діяльність підприємств різних галузей i поширення змісту цього поняття не лише на осіб з особливими 
потребами, а й на усіх працівників, які можуть бути залучені до робочого процесу у різних формах і на різних умовах трудової діяльності, явище інклюзивності робочого місця стає все більш вагомим для підвищення якісних характеристик працівників підприємств.

Зміст інклюзивності робочого місця полягає у наявності рівних можливостей залучення до роботи та прийняття рішень для усіх категорій співробітників компанії чи організації незалежно від їх раси, етнічної приналежності, статі, фізичних можливостей, віку, стану здоров'я та інших особистих якостей, крім передбачених професійними вимогами до певної спеціальності або посади. Дослідники зазначають, що інклюзивні організації в 1,8 рази частіше можуть бути готовими до змін і в 1,7 рази частіше бути лідерами на своєму ринку в галузі інновацій, а також сприяють збільшенню продуктивності праці різноманітної за особистісними якостями робочої сили, що веде до збільшення грошових потоків компанії [1].

Інклюзивність робочого місця містить такі складові:

- «внутрішньоособистісна інклюзивність», тобто особиста впевненість співробітників у тому, що їх чують, вислуховують, поважають, цінують, забезпечують психологічну безпеку, справедливо ставляться до них, вони мають почуття приналежності до колективу;

- «міжособистісна інклюзивність» - забезпечення інклюзивних умов праці на рівні керівництва різних рівнів, взаємодії 3 колегами, у робочій команді / колективі;

- «зовнішня інклюзивність», тобто ступінь інклюзивності робочого місця та організації (компанії) в цілому: культура компанії, формальне закріплення етичних норм, організація робочих процесів та процесів прийняття рішень, доступ до інформації, можливості професійного та особистісного розвитку.

Виділяють також форми прояву інклюзивності робочого місця [2]: 
- доступність та участь - здатність говорити 3 будь-якої персоною в організації / компанії, доступність до керівництва та ресурсів, здатність взаємодіяти у колективі;

- використання умінь та завдання - включення працівників у виконання проектів відповідно до рівня їх умінь і навичок, призначення та розподіл завдань на основі умінь і здатностей працівників, участь їх у стратегічних ініціативах;

- навчання та зростання - підтримка професійного розвитку працівників, участі у конференціях та інших професійних заходах, регулярна підготовка звітів щодо навчання працівників;

- компенсації та вигоди від кар'єрних можливостей - прозора структура надання компенсацій, належна заробітна платня, зростання заробітної платні відповідно до підвищення відповідальності, доступність високооплачуваної роботи / проектів / робочих місць для усіх працівників;

- баланс між роботою та особистим життям - доступність гнучкого робочого графіку, допомога у догляді за дітьми, старшим поколінням, сімейна політика підприємства;

- повага - врахування усіх думок працівників, впевненість у тому, що завдання розподіляються справедливо, відсутність переслідувань чи пригнічень на колективних зборах, впевненість, що внесок кожного працівника настільки ж вагомий, як і внески його колег.

Інклюзивність не $є$ стабільним станом, вона потребує постійної підтримки від роботодавців та самих співробітників, тому оцінка інклюзивності робочого місця є достатньо важкою, особливо у кількісному аспекті, що, у результаті, ускладнює вироблення ефективних пропозицій щодо стимулювання розвитку людського капіталу працівників підприємства. Застосування традиційних соціологічних методів дослідження інклюзивності робочого місця базується на роботі з фокус-групами, проведенні опитувань, застосування нових аналітичних інструментів та цифрових технологій [3]. Для оцінки інклюзивності робочих місць проводяться також опитування співробітників компаній iз застосуванням анкет 3 переліком та частотою «випадків 
виключення», тобто випадків, коли працівники почуваються «виключеними» 3 робочого процесу (процесу прийняття рішень, доступу до інформації, тощо).

До якісних показників оцінки інклюзивності робочого місця належать такі: задоволеність працівників, залучення до спільноти (особисті уявлення співробітників про їх цінність для колективу), відносини між працівниками, щирість відповідей працівників при опитуваннях, можливість вільних висловлювань без негативних наслідків, відчуття дискримінації або утисків, вільне та чесне керівництво тощо.

Кількісними показниками оцінки інклюзивності робочого місця є: рівень різноманітності колективу, продуктивність праці, різноманітність персонального складу керівних органів, рівень соціальної дистанції у колективі, умови праці, інноваційність і креативність, кар'єрне зростання і його доступність (показники просування по службі), ознайомлення 3 особливостями різних культур, порядок розгляду скарг та питань трудових відносин для різних категорій працівників тощо [4].

Використовується й такий кількісний показник як індекс включення (може розроблятись як для організацій та компаній, так і персональний - для окремих категорій працівників), який формується на основі даних соціологічних опитувань про вплив працівників на прийняття рішень, доступ до важливої інформації для виконання роботи, безпечні умови праці, задоволеність роботою, добробут людей, прихильність роботодавця до включення та результати трудової діяльності групи [5].

Компанією McKinsey розроблено індекс загальної інклюзії, який складається 3 «Особистого досвіду працівників» (Personal experience) та «Сприйняття підприємства» (Enterprise perception) [6]. «Особистий досвід працівників» показує: як співробітники особисто відчувають свою приналежність до колективу компанії та зв'язки 3 іншими працівниками, чи відчувають вони заохочення брати участь у роботі в повному обсязі, чи мають право голосу у прийнятті командних рішень, чи відчувають важливість і значимість свого внеску у роботу компанії та прина- 


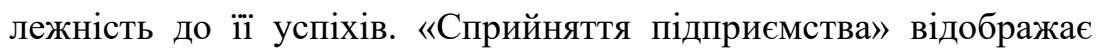
такі позиції як: чи бачать співробітники цінність у різноманітності, чи поділяють вони спільні цінності та спільну роботу для їх досягнення, чи є справедливе та неупереджене оцінювання результатів діяльності, чи існує у компанії рівне ставлення до усіх працівників і чи кожен з них має шанс на досягнення успіху. Порівнюючи ці складові, можна виділити розбіжності, які можуть виникнути між діями компанії, спрямованими на підвищення інклюзивності робочих місць, та сприйняттям конкретних проявів інклюзивності працівниками компанії, що дозволить як визначити ефективність заходів щодо підвищення інклюзивності робочих місць, так і окреслити шляхи розвитку людського капіталу їі працівників.

Ще один 3 методів оцінки інклюзивності робочих місць технологія аналізу організаційної мережі TrustSphere, тобто використання даних із систем корпоративної комунікації таких як електронна пошта, миттєві повідомлення та телефони [7]. Вона дозволяє вимірювати відносини на робочому місці, які підтримуються співробітниками, як в середині робочого колективу, так $\mathrm{i}$ 3 контрагентами. При цьому досліджуються не зміст або теми повідомлень, а лише показники міцності кожної взаємодії або зв'язку в мережі взаємодій та мережевої активності, тобто відносної здатності співробітника здійснювати вплив у своїй робочій команді чи на підприємстві в цілому.

\section{Лiтература:}

1. Work in Culture (n.d.), Inclusive HR toolkit - Part 5 measuring. URL: http://www.workinculture.ca/Resources/Inclusion-in-the-Creative-Workplace/InclusiveHRToolkit/Part-6-Measuring-Success/Tools.

2. Measuring the invisible. Why and how you should measure inclusion. URL: https://aleria.tech/inclusion-assessment.

3. Young Mary. 2019. More Than a Feeling: Measuring Workplace Inclusion. URL: https://www.workdesign.com/2019/03/more-than-a-feeling-measuring-workplace-inclusion.

4. Fitzpatrick S., Sharma M. Can inclusion be measured in a quantitative way, just qualitative, or a combination? Retrieved from Cornell University, ILR School. 2017. URL: http://digitalcommons.ilr.cornell.edu/student/152. 
5. Leith Mitchell. 2017. Measuring inclusion. URL: https://www.linkedin.com/ pulse/ measuring-inclusion-leith-mitchell.

6. Ellsworth D., Goldstein D., Schaninger B. 2021. Inclusion doesn't happen by accident: Measuring inclusion in a way that matters. URL: https://www. mckinsey.com.

7. Newman G. 2019. Moving from counting Diversity to measuring Inclusion. URL: https://www.trustsphere.com/moving-from-counting-to-measuring-inclusion. 